\title{
VOLUNTEER'S ENGAGEMENT: FACTORS AND METHODS TO INCREASE VOLUNTEER'S PERFORMANCE AND PRODUCTIVITY IN NGOS DURING COVID-19 PANDEMIC (SCOUT ORGANIZATIONS AS A MODEL)
}

\author{
Ela ABDULKADIR \\ Istanbul Sabahattin Zaim University, Istanbul, Turkey \\ ala.khader@std.izu.edu.tr \\ Nicoleta ISAC \\ Istanbul Sabahattin Zaim University, Istanbul, Turkey \\ nicoleta.isac@izu.edu.tr \\ Cosmin DOBRIN \\ Bucharest University of Economic Studies \\ cdobrin@yahoo.com
}

\begin{abstract}
Since the scout movement plays an important role in communities and contributes to the development of young people in many ways, it was necessary to preserve a productive team to keep the scout organization to the right way. Due to the lack of research that carried out in this field, this paper studies the best ways to increase the performance of volunteers in NGOs especially scout organizations during COVID-19. The descriptive research used a cross-sectional design, and the data was collected using quantitative and qualitative research methods. There were conducted 7 online meetings with seven top managers in different scout organizations and analyzed 154 questionnaire responses from volunteers. The results approved the research hypothesis of the positive relationship between McClelland's Human Motivation Theory which is the need for achievement, affiliation, and power, and its impact on the high performance of volunteers during the COVID-19 pandemic. Besides, training, development, enhancing skills and communication are the best ways to motivate volunteers in the team as concluded.
\end{abstract}

Keywords: NGOs, motivation, scout, Covid-19, performance.

DOI: https://doi.org/10.24818/beman/2021.S.I.2-02

\section{INTRODUCTION}

Changes in the markets make companies change their strategies and apply new methods to meet the needs and desires of their customers (Veselovská et al., 2021). 
Abdulkadir, E., Isac, N., \& Dobrin, C.

\section{VOLUNTEER'S ENGAGEMENT: FACTORS AND METHODS TO INCREASE VOLUNTEER'S PERFORMANCE AND} PRODUCTIVITY IN NGOS DURING COVID-19 PANDEMIC (SCOUT ORGANIZATIONS AS A MODEL)

No one can deny that NGOs which are non-profit organizations have big impact on societies, because of different kinds of gaps that cover in communities. Folger (2021) defines NGOs as they are national or international organizations which serve social or political goals such as humanitarian causes or the environment. According to Lewis (2009) NGOs are best-known for the delivery of services to people in need, but and many other areas as human rights work, cultural preservation, environmental activism and so on. One of the most important NGO is scout organization which is a voluntarily non-political educational movement for young people in accordance with the principles of it's founder (Baden, 1907). Scouting has been subscribed by more than one enthusiast as a revolution in education and since, is a complementary to school training and give the information to boys and girls in creative ways in nature. It's objective is to encourage the physical, intellectual, social, emotional and spiritual development of young people so that they take a constructive place in society as responsible citizens. It was important to have a spotlight on the work team of scouting and volunteer leaders that manage these scout groups around the world due to the importance of human capital especially during COVID-19 pandemic that we live it nowadays. This paper examines the problem of drop out of the volunteers from NGOs during COVID-19 especially from scout organization. It presents a new approach of how the top management can preserve an active and productive volunteers by applying McClelland's Human Motivation Theory on the field of volunteers that work in scout organizations by enhancing training and development to increase their skills and communication. Since the next decade, will witness different tools and methods of how to keep volunteers engaged at work and how to use innovation in increasing the performance of volunteers at the field of NGOs. Although the scout movement have a significant impact on young people, there are little research papers are carried out in the field of human resources of scout organizations. In addition, approximately there is no papers were published of how the scout response to the COVID-19 pandemic. Moreover, what make the mission of talking about this problem in the research harder is that scout activities are relying on the physical existence and face to face training outdoors with several boys or girls. On the other hand, everyone can see the procedures that governments made all over the world to protect humans' lives from this pandemic. Lockdown cause a kind of depression on the top management of NGOs especially of scout leaders that used to meet in different adventures and discovering new places and the sudden cutout of activities with scouts. Schmidt (2016) says that there are several motivators that managers can affect, thereby modifying a volunteers' behavior, the factors that can be controlled by managers are: the perceived social meaningfulness of volunteer activity. Brooks (2002) demonstrates that the opportunity to enhance the volunteers' career with respect to both skills and resume building, and positive organizational culture. Millette and Gagné (2008) mentions that job characteristics are related to volunteers' autonomous 
Abdulkadir, E., Isac, N., \& Dobrin, C.

VOLUNTEER'S ENGAGEMENT: FACTORS AND METHODS TO INCREASE VOLUNTEER'S PERFORMANCE AND PRODUCTIVITY IN NGOS DURING COVID-19 PANDEMIC (SCOUT ORGANIZATIONS AS A MODEL)

motivation, satisfaction and performance while Nencini et al. (2015) shows that the organizational climate mediates the relationship between motivation and satisfaction. However, there are still some questions need clear answers, and gaps need to cover, like the best way of treatment between top management and volunteers during this Covid-19 pandemic. This paper examines all the challenges and present the ideal ways to deal with this tough period by introducing solutions for the leaders who manage scout teams to increase the volunteer's performance and keep them motivated until reaching leadership in scouting. Moreover, a better understanding of nonprofit governance could advance the human quest for social justice (Wagner, 2015).

\section{THEORETICAL BACKGROUND AND HYPHOTESES DEVELOPMENT}

\subsection{McClelland needs theory}

The psychologist McClelland (1961) identified a new theory of needs that human beings have. He identified three motivators for people at work which can get a productive person and this theory was called McClelland needs theory or three needs theory or learned needs theory. These needs are: need for achievement, need for affiliation, need for power. People have different characteristics depending on their dominant motivator at work and how it affects the performance of employees and volunteers in a positive way. To have a better look on these needs Osemeke and Adegboyega (2017) characterized them by:

1) Need for power: people who have this need normally they enjoy controlling the others, and they like to have a good position at work to be motivated for working. People who have high need for power are characterized by:

- A desire to influence and direct somebody else.

- A desire to exercise control over others.

- A concern for maintaining leaders-follower relations.

2) Need for achievement: people who have this need normally like standards and deadlines, they want to work at organizations which have a lot of challenges and competitions. People who have high need for achievement are:

- Have a strong desire to assume personal responsibilities for performing a task of finding a solution to a problem.

- Look for challenging tasks.

- Have a strong desire for performing feed-back. 
Abdulkadir, E., Isac, N., \& Dobrin, C.

VOLUNTEER'S ENGAGEMENT: FACTORS AND METHODS TO INCREASE VOLUNTEER'S PERFORMANCE AND PRODUCTIVITY IN NGOS DURING COVID-19 PANDEMIC (SCOUT ORGANIZATIONS AS A MODEL)

3) Need for affiliation: usually, people who have the need of affiliation want to be liked from others, they enjoy an environment where making friends are the big motive for them to keep them engaged at work. Their characteristics are:

- They have a strong desire for acceptance and approval from others.

- They tend to conform to the wishes of those people whose friendship and companionship they value.

- They value of the feeling of others.

The top management of NGOs and scouting organizations must analyze the volunteer's characteristics and imply the best ways of motivators depending on each one to keep them productive and active, therefore they will become the best NGO or the best scout organization comparing to their competitors.

\subsection{Covid-19 pandemic}

Cases of COVID-19 were first identified in December 2019, when mysterious illness was reported in Wuhan, China, on $11^{\mathrm{TH}}$ March. The World Health Organization officially announced that the outbreak should be considered as a pandemic after the infection was spread to several countries around the globe (Kassema, 2020).

As a result, some of organizations closed and some of them still working remotely due to the lockdown and the huge number of deaths around the world because of the pandemic. Scout organizations also became applying its activities online and on social media platforms to keep its people engaged, but unfortunately, some of them was closed and could not apply its programs. According to Kassema (2020) African developing countries have just started to introduce video conferencing, net meetings as well as digital document management systems and electronic file sharing, but still have long way to go, the gap is so huge in terms of technological solutions, infrastructure as well as expertise.

The core problem of most of NGOs and scout organizations is the lack of funding in supporting an online human resources system, it is challenging but it is not impossible. In this regard, organization can search for an affordable engagement system and digitalize everything, because of this we can put the organization in a sustainable way and keep it to the pioneer masters. Oak and Schoeffler (2020) suggests that managers must communicate well with their employees during the pandemic by making effective virtual meetings and trying to help them with their immediate needs and concerns. Moreover, they should offer recognition and encouragement by sending regular emails to the staff to reassure them that their role is essential. Taking in consideration all these aspects we can say there is obviously a need for government measures and policies to manage this situation and minimize the negative effects (Tonnoir et al., 2021). 


\section{Abdulkadir, E., Isac, N., \& Dobrin, C. \\ VOLUNTEER'S ENGAGEMENT: FACTORS AND METHODS TO INCREASE VOLUNTEER'S PERFORMANCE AND PRODUCTIVITY IN NGOS DURING COVID-19 PANDEMIC (SCOUT ORGANIZATIONS AS A MODEL)}

\subsection{Scouting}

The scouting movement is a non-formal educational organization, which is defined by the United National Educational Scientific and Cultural Organization (UNESCO) as having organized educational activity outside the established formal system (Lim, 2014).

According to Rajamanikam (2016) the original ideas of scouting are strengthening the character and personality, and increase the capacity and resistance, moreover the development of manual skills and sense of security in one's ability.

The Scout Movement was found in 1922 in Paris, France and there are 54 million scouts, making the world's largest coordinated youth contribution to the SDGs (Sustainable Development Goals) according to World Organization of the Scout Movement (2020). Considering the above-mentioned reasons, the human capital of scout organization is the fuel of the success. In the literature there are many researches were carried out about the motivation of human capital in the non-governmental organizations, but it failed to address the field of volunteers, most of them about employees who receiving salaries from managers. In his research Mose (2019) indicated that we can increase the employment performance by increase in employment contracts, training and development and leadership style. Ireri (2015) recommended NGOs to develop and implement a payment policy to attract sufficient employees, come up with a clear promotion and career advancement policy, develop an organizational structure to communicate to employees on different levels of authority and enhance employee recognition with financial reward. However, there is still a need for studying the field of volunteerism not just employment in NGOs. Pacesila (2014) analyzed different ways of motivating volunteers intrinsically (like relationship between volunteers, contact with communities, the beneficiaries of the organization's activities and the acquisition of knowledge in the field of minority rights) and extrinsically (like training programs, voluntary agreements, certificates for volunteering public recognition of the efforts, gift-giving, volunteers consulting). Nevertheless, it was important to analyze the environment of volunteer leaders at scout organization and discover the effective ways of volunteer's retention. Czepial (1992) demonstrates that volunteer leaders are empowered by his or her awareness of social issues, and by practicing in decision-making that affects the volunteer organization's actions and influences. However, this research will go in more details about the investigation of relationship between NGOs and volunteers.

\subsection{Research questions:}

1. Does the feeling of achievement, and affiliation and power increase the performance of volunteers in NGOs particularly in scout organization during COVID-19 pandemic? 
Abdulkadir, E., Isac, N., \& Dobrin, C.

\section{VOLUNTEER'S ENGAGEMENT: FACTORS AND METHODS TO INCREASE VOLUNTEER'S PERFORMANCE AND PRODUCTIVITY IN NGOS DURING COVID-19 PANDEMIC (SCOUT ORGANIZATIONS AS A MODEL)}

2. What are the important motives that maintain volunteers in NGOs particularly in scout organization during COVID-19 pandemic?

3. What things that scout organization must add or change to enhance the performance of volunteers in NGOs espaecially scout organization during COVID-19 pandemic?

4. What are the factors that make volunteers dissatisfied in NGOs especially in scout organizations during COVID-19 pandemic?

\subsection{Hypothesis:}

1. The feeling of achievement enhance the performance of volunteers in NGOs espeacially in scout organizations during COVID-19 pandemic.

2. The feeling of affiliation increase the productivity of volunteers in NGOs especially in scout 3organizations during COVID-19 pandemic.

3. The feeling of power rise volunteer's engagement in NGOs especially in scout organizations during COVID-19 pandemic.

4. Training and development play a crucial role in enhancing the productivity of volunteers in NGOs particularly in scout organizations during COVID-19 pandemic.

\section{RESEARCH METHODOLOGY}

\subsection{Research technique}

This paper is a type of descriptive research where it describes the situation of NGOs and scout organizations during COVID-19 and how they deal with their volunteers and what are the best factors to motivate them. The research focuses on the characteristics of successful management during the pandemic and how it handles the organization and keep it to the safe way. It analyzes the relationship between variables like demographic information and its relation with motivation needs in order to solve conclude the best solution of volunteer's retention.

\subsection{Research design}

Cross-sectional data was collected as research design which it studies data from many different volunteers at a single point in time. The paper analyzes variables like age, gender, scout organization's name, social status, qualification, and the correlation between them with type of motivation that is needed for each variable. 


\section{Abdulkadir, E., Isac, N., \& Dobrin, C. \\ VOLUNTEER'S ENGAGEMENT: FACTORS AND METHODS TO INCREASE VOLUNTEER'S PERFORMANCE AND PRODUCTIVITY IN NGOS DURING COVID-19 PANDEMIC (SCOUT ORGANIZATIONS AS A MODEL)}

\subsection{Research method and data collection}

This research was carried out in two stages, the first stage was collecting data in a qualitative method by conducting 7 online meetings with top managers of different scout organizations, every meeting last for 35 minutes, this stage enables to gather in-depth insights on the situation and procedures that were done by top management for evert scout organization.

There were structured questions to answer, and the interview was divided into three parts:

- the first part if the organization was working during the pandemic or was it closed;

- the second part about the way of motivation policy that organization used to its volunteers;

- the third part about how many members the organization have and its impact on society.

The 7 top managers of these scout organizations were from Libya, Jordan, Syria, Turkey, Palestine, and one of these organizations was found in 1975.

The second stage was self-administrative questionnaire by quantitative method, there were 20 questions in the survey, 5 demographic questions, 12 Likert scale questions related to the research questions, and three open-ended questions.

\subsection{Sampling}

The simple random sampling probability was used in this research, which each member of volunteers has an exactly equal chance of being selected. The sample size was 154 respondents from 35 different scout organizations from different countries.

\subsection{Data analysis}

The data was analyzed using charts, bars and tables. According to QuestionPro (2021), research data analysis is a process used by researchers for reduction data to a story and interpreting it to derive insights. Some data was edited due to the errors because some respondents filled some fields incorrectly, then the data was coded and transformed to meaningful categories and interpreted in the discussion section. Qualitative data was analyzed into a table using content analysis technique.

\section{FINDINGS AND RESULTS}

\subsection{Qualitative findings:}

There were conducted 7 online meetings with 7 top managers of different scout organizations, and they were asked 3 structured questions related to the research questions in order to analyze the best way to 
Abdulkadir, E., Isac, N., \& Dobrin, C.

VOLUNTEER'S ENGAGEMENT: FACTORS AND METHODS TO INCREASE VOLUNTEER'S PERFORMANCE AND PRODUCTIVITY IN NGOs DURING COVID-19 PANDEMIC (SCOUT ORGANIZATIONS AS A MODEL)

motivate volunteers in non-governmental organizations especially in scout organizations, and trying to solve the problem of volunteers' drop out during COVID-19 pandemic.

The results were categorized into the following table:

TABLE 1. QUALITATIVE FINDINGS

\begin{tabular}{|c|c|c|c|}
\hline Scout Organizations & $\begin{array}{c}\text { Was your scout } \\
\text { organization working } \\
\text { during the pandemic? }\end{array}$ & $\begin{array}{l}\text { As a top management, } \\
\text { what are the best ways } \\
\text { to motivate your team } \\
\text { during the pandemic? }\end{array}$ & $\begin{array}{c}\text { How many team } \\
\text { members do you have? }\end{array}$ \\
\hline Org 1 & Yes & $\begin{array}{l}\text { Using the online } \\
\text { promotion system }\end{array}$ & 6 \\
\hline Org 2 & $\begin{array}{l}\text { Yes, then activities were } \\
\text { cancelled. }\end{array}$ & $\begin{array}{l}\text { Volunteering certificate, } \\
\text { promote personal } \\
\text { volunteer's projects } \\
\text { between members, free } \\
\text { trips, free training courses } \\
\text { for volunteers, present } \\
\text { university scholarships, } \\
\text { securing jobs for } \\
\text { volunteers in their career } \\
\text { journey }\end{array}$ & 10 \\
\hline Org 3 & Yes, then it was closed & $\begin{array}{l}\text { Involve volunteers in } \\
\text { decision making, high } \\
\text { recognition, online } \\
\text { meetings and personal } \\
\text { relations building, } \\
\end{array}$ & 5 \\
\hline $\operatorname{Org} 4$ & yes & $\begin{array}{c}\text { Training and development } \\
\text { of volunteers, provide } \\
\text { them of learning and } \\
\text { information. }\end{array}$ & 160 \\
\hline Org 5 & yes & $\begin{array}{c}\text { Online workshops } \\
\text { between volunteers, } \\
\text { educational lectures, } \\
\text { increase the awareness of } \\
\text { organization's vision } \\
\text { importance in community. }\end{array}$ & 15 \\
\hline Org 6 & yes & $\begin{array}{l}\text { Training programs, } \\
\text { lectures about scouting } \\
\text { importance, monthly } \\
\text { online meetings, } \\
\text { honorable meetings, } \\
\text { reassuring volunteers. }\end{array}$ & 60 \\
\hline $\operatorname{Org} 7$ & Yes, then it was closed & $\begin{array}{l}\text { live lectures with famous } \\
\text { guests presented by } \\
\text { volunteers on social } \\
\text { media, }\end{array}$ & 20 \\
\hline
\end{tabular}

Source: Personal collection 
Abdulkadir, E., Isac, N., \& Dobrin, C.

VOLUNTEER'S ENGAGEMENT: FACTORS AND METHODS TO INCREASE VOLUNTEER'S PERFORMANCE AND PRODUCTIVITY IN NGOS DURING COVID-19 PANDEMIC (SCOUT ORGANIZATIONS AS A MODEL)

The results show that every scout organization uses different motivation tools forward its volunteers, like decision making involvement, enhance the need of affiliation, and get volunteers plan and achieve goals. Moreover, training and development and enhance skills of volunteers motivate them to be productive and effective in the team and in communities.

\subsection{Quantitative findings:}

The research targeted 100 respondents and 156 questionnaires were answered for analysis, the response rate was $156 \%$, so it was more than good. The questionnaire was published by many scout organizations between volunteers and supported well.

Demographic characteristics of the respondents

TABLE 2. AGE DISTRIBUTION

\begin{tabular}{|l|l|l|}
\hline age & frequency & percentage \\
\hline $\mathbf{1 6 - 2 0}$ & 22 & $14 \%$ \\
\hline $\mathbf{2 1 - 2 5}$ & 69 & $45 \%$ \\
\hline $\mathbf{2 6 - 3 0}$ & 13 & $9 \%$ \\
\hline $\mathbf{3 1 - 3 5}$ & 12 & $\mathbf{7} \%$ \\
\hline $\mathbf{3 6 - 4 0}$ & 9 & $6 \%$ \\
\hline $\mathbf{4 1 - 4 5}$ & 7 & $5 \%$ \\
\hline $\mathbf{4 6 - 5 0}$ & 11 & $\mathbf{7} \%$ \\
\hline $\mathbf{5 1 - 5 5}$ & 3 & $\mathbf{2} \%$ \\
\hline $\mathbf{5 6 - 6 0}$ & 5 & $3 \%$ \\
\hline $\mathbf{6 1 - 6 5}$ & 3 & $\mathbf{2} \%$ \\
\hline Total & 154 & $\mathbf{1 0 0} \%$ \\
\hline & \multicolumn{2}{|c|}{ Source: Personal collection } \\
\hline
\end{tabular}

The respondents who participated to the study were $73 \%$ female, and $81 \%$ were male. We can observe that respondents with age between 21 to 25 represent $45 \%$ (highest) while the percentage of volunteers who are from age 61 to 65 is $2 \%$ (lowest). The average range of age distribution is 29 . 
Abdulkadir, E., Isac, N., \& Dobrin, C.

VOLUNTEER'S ENGAGEMENT: FACTORS AND METHODS TO INCREASE VOLUNTEER'S PERFORMANCE AND PRODUCTIVITY IN NGOS DURING COVID-19 PANDEMIC (SCOUT ORGANIZATIONS AS A MODEL)

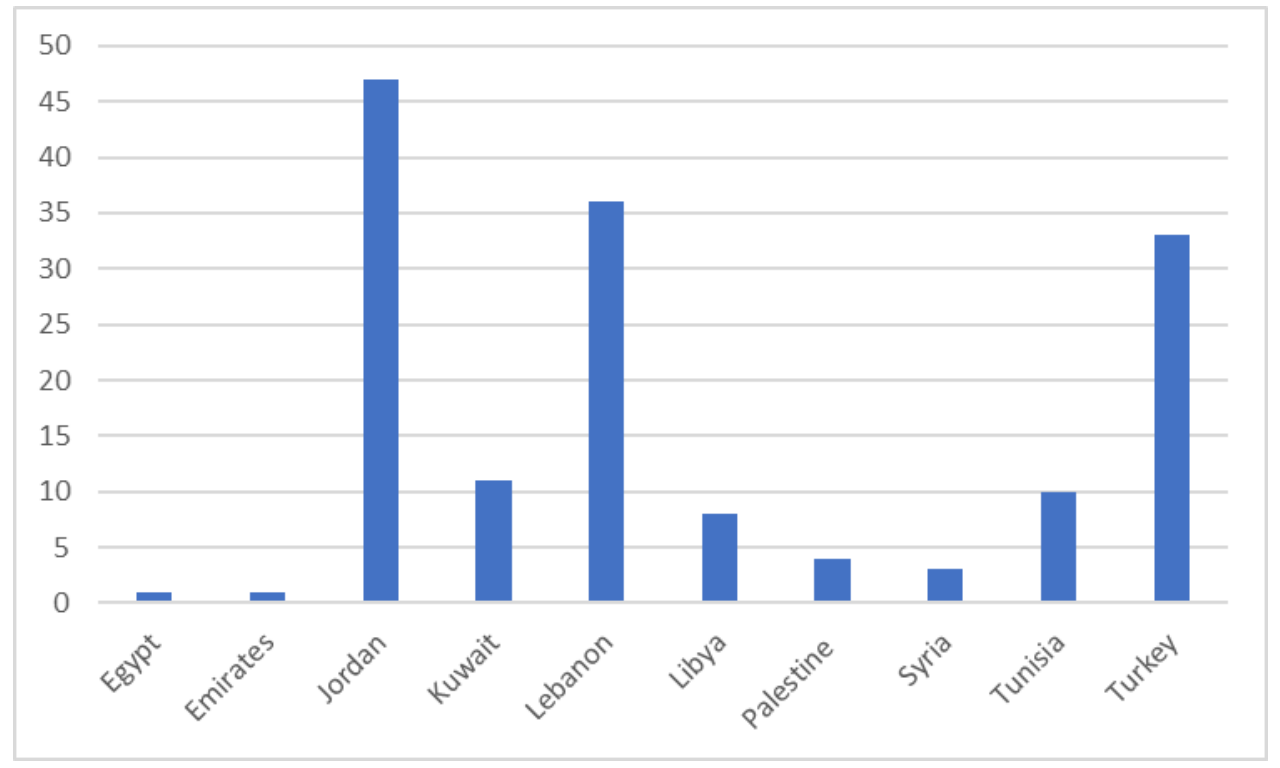

GRAPHIC 1. COUNTRY OF RESIDENCE

Source: Personal collection

Most of the respondents are from Jordan and the percentage was $47 \%$, then from Lebanon $36 \%$, and respondents from Turkey $33 \%$, Kuwait is $11 \%$, Tunisia is $10 \%$, Libya is $8 \%$, Palestine is $4 \%$, Syria is $3 \%$, and both Egypt and United Arab Emirates are 1\% each.

\section{McClelland's theory of needs questions' findings}

The questionnaire had 9 Likert scale questions related to the affiliation, achievement, and power needs in order to conclude the results of how much do these needs affect volunteers' motivation. Respondents answered one of five multiple choices: (SA) strongly agree, (A) agree, (U) undecided, (D) disagree, (SD) strongly disagree.

\section{Need for affiliation findings:}

TABLE 3. THE DEGREE TO WHICH THE ORGANIZATION AFFECTED POSITIVE LIFE DURING COVID-19

\begin{tabular}{|c|c|c|}
\hline Scale & Frequency & Percentage \\
\hline Strongly agree & 50 & $32 \%$ \\
\hline Agree & 37 & $24 \%$ \\
\hline Undecided & 36 & $23 \%$ \\
\hline Disagree & 17 & $11 \%$ \\
\hline Strongly disagree & 14 & $9 \%$ \\
\hline Total & 154 & $100 \%$ \\
\hline
\end{tabular}


Abdulkadir, E., Isac, N., \& Dobrin, C.

VOLUNTEER'S ENGAGEMENT: FACTORS AND METHODS TO INCREASE VOLUNTEER'S PERFORMANCE AND PRODUCTIVITY IN NGOS DURING COVID-19 PANDEMIC (SCOUT ORGANIZATIONS AS A MODEL)

The table indicates that $32 \%$ of respondents strongly agree about the fact that scout organization affects positively on their lives during COVID-19 pandemic, $24 \%$ of them agree about the fact, $23 \%$ are undecided, $11 \%$ of them disagree with the fact, and $9 \%$ strongly disagree with the fact.

TABLE 4. THE DEGREE TO WHICH THE ORGANIZATION GAVE THE NEEDED AFFILIATION DURING COVID-19.

\begin{tabular}{|c|c|c|}
\hline Scale & Frequency & Percentage \\
\hline Strongly agree & 34 & $22 \%$ \\
\hline Agree & 47 & $31 \%$ \\
\hline Undecided & 39 & $25 \%$ \\
\hline Disagree & 20 & $13 \%$ \\
\hline Strongly disagree & 14 & $9 \%$ \\
\hline Total & 154 & $100 \%$ \\
\hline
\end{tabular}

Source: Personal collection

The table indicates that $22 \%$ of respondents strongly agree that scout organization gave them the affiliation that they need during COVID-19 pandemic, $31 \%$ of them agree with the fact, $25 \%$ are undecided, $13 \%$ of respondents disagree with the fact, and $9 \%$ strongly disagree with the fact. The third question that related to affiliation need was:

TABLE 5. THE DEGREE TO WHICH TOP MANAGEMENT COMMUNICATE WELL WITH VOLUNTEERS DURING COVID-19

\begin{tabular}{|c|c|c|}
\hline Scale & Frequency & Percentage \\
\hline Strongly agree & 78 & $51 \%$ \\
\hline Agree & 37 & $24 \%$ \\
\hline Undecided & 16 & $10 \%$ \\
\hline Disagree & 6 & $4 \%$ \\
\hline Strongly disagree & 17 & $11 \%$ \\
\hline Total & 154 & $100 \%$ \\
\hline
\end{tabular}

Source: Personal collection

The table indicates that $51 \%$ of respondents strongly agree with the fact that top management treat them with love like they are a family during COVID-19 pandemic, 24\% agree with the fact, $10 \%$ are undecided, $4 \%$ of them disagree with the fact, and $11 \%$ strongly disagree with the fact.

\section{Need for achievement findings:}

The respondents were asked also three questions to measure the degree of which top management satisfies the need of achievement, and in the table below shows the average range of responses of the three questions. 
Abdulkadir, E., Isac, N., \& Dobrin, C.

VOLUNTEER'S ENGAGEMENT: FACTORS AND METHODS TO INCREASE VOLUNTEER'S PERFORMANCE AND PRODUCTIVITY IN NGOS DURING COVID-19 PANDEMIC (SCOUT ORGANIZATIONS AS A MODEL)

TABLE 6. THE DEGREE TO WHICH ORGANIZATION PROVIDES TRAINING, LEARNING, AND COMPETITION TO VOLUNTEERS DURING COVID-19

\begin{tabular}{|c|c|c|}
\hline Scale & frequency & percentage \\
\hline Strongly agree & 43 & $28 \%$ \\
\hline Agree & 43 & $28 \%$ \\
\hline Undecided & 31 & $20 \%$ \\
\hline Disagree & 21 & $14 \%$ \\
\hline Strongly disagree & 15 & $10 \%$ \\
\hline Total & 154 & $100 \%$ \\
\hline
\end{tabular}

Source: Personal collection

As we can see from the table that respondents who strongly agree and agree with these facts about need for achievement are 43, undecided 31, the respondents that disagree 21, and who strongly disagree are 15.

\section{Need for power findings:}

The respondents were asked also three questions to measure the degree of which top management satisfies the need of power, and in the table below shows the average range of responses of the three questions.

TABLE 7. THE DEGREE TO WHICH ORGANIZATION VALUE VOLUNTEERS' OPINION, DELEGATE THEM, AND RELY ON THEM IN CRITICAL TASKS DURING COVID-19

\begin{tabular}{|c|c|c|}
\hline Scale & Frequency & Percentage \\
\hline Strongly agree & 58 & $38 \%$ \\
\hline Agree & 48 & $31 \%$ \\
\hline Undecided & 16 & $10 \%$ \\
\hline Disagree & 16 & $10 \%$ \\
\hline Strongly disagree & 16 & $11 \%$ \\
\hline Total & 154 & $100 \%$ \\
\hline
\end{tabular}

Source: Personal collection

The table indicates that 58 respondents strongly agree with the three status of power needs, 48 of them agree with the facts, 16 of them undecided, 16 disagree, and 16 strongly disagree.

\section{Findings of open-end questions}

The respondents were asked three open-end questions to know the best way of motivation of volunteers in NGOs during COVID-19 pandemic. The questions were related to what people want for themselves (Neculaesei et al., 2019). 
Abdulkadir, E., Isac, N., \& Dobrin, C.

VOLUNTEER'S ENGAGEMENT: FACTORS AND METHODS TO INCREASE VOLUNTEER'S PERFORMANCE AND PRODUCTIVITY IN NGOS DURING COVID-19 PANDEMIC (SCOUT ORGANIZATIONS AS A MODEL)

The first open-end question was about the most important factors that motivate volunteers to have an effective performance in the organization during the pandemic, and the findings related with the second open-end question that respondents answered about dissatisfaction factors in NGOs and scout organizations in order to correlate it with McClelland's theory of needs.

The last open-end question in the questionnaire was about the important factors that must scout organization add or change in managing the team to motivate the volunteer leaders.

The table below shows the results and findings as following:

\section{TABLE 8. MOTIVATION, DISSATISFACTION, MANAGEMENT ROLE FACTORS TO INCREASE THE PRODUCTIVITY OF VOLUNTEERS}

\begin{tabular}{|c|c|c|}
\hline $\begin{array}{l}\text { Volunteer motivation in } \\
\text { NGOs organizations }\end{array}$ & $\begin{array}{c}\text { Factors of } \\
\text { dissatisfaction in NGOs }\end{array}$ & $\begin{array}{c}\text { Factors that top } \\
\text { management must add } \\
\text { or change to increase } \\
\text { volunteers' motivation }\end{array}$ \\
\hline Community service & $\begin{array}{l}\text { Neglecting volunteers' } \\
\text { opinions }\end{array}$ & $\begin{array}{c}\text { Pay attention to } \\
\text { volunteers' opinion }\end{array}$ \\
\hline $\begin{array}{l}\text { Self-development and } \\
\text { self-responsibility }\end{array}$ & $\begin{array}{l}\text { Not participating in the } \\
\text { decision making }\end{array}$ & $\begin{array}{l}\text { Decision making } \\
\text { involvement of } \\
\text { volunteers }\end{array}$ \\
\hline $\begin{array}{c}\text { Faith and religious } \\
\text { motives }\end{array}$ & Lack of inspiration & More ideas generation \\
\hline $\begin{array}{l}\text { Passion, affiliation, } \\
\text { serenity }\end{array}$ & Weak promotion system & Imply clear task division \\
\hline $\begin{array}{l}\text { Communication with } \\
\text { new people and building } \\
\text { good generation }\end{array}$ & Poor communication & $\begin{array}{c}\text { Imply an effective } \\
\text { communication between } \\
\text { top management and } \\
\text { volunteers }\end{array}$ \\
\hline Leadership building & High centralization & $\begin{array}{l}\text { Enhance an effective } \\
\text { promotion system }\end{array}$ \\
\hline Gain new experience & Lack of training & Delegate volunteers \\
\hline Love for learning & $\begin{array}{l}\text { Lack of achievement } \\
\text { environment }\end{array}$ & $\begin{array}{c}\text { Increase skills } \\
\text { development of } \\
\text { volunteers }\end{array}$ \\
\hline
\end{tabular}

Source: Personal collection

The table shows different motives of volunteers to work at NGOs and scout organizations, and these motives related to McClelland's theory of needs. Moreover, we can see from the table, some respondents express their dissatisfaction by these statements related to McClelland's needs theory. Therefore, the answers indicate that top management must be aware of the changes that must be done to engage volunteers in the organization and make them love what they do. 


\section{DISCUSSION}

The results above show that McClelland's theory of needs affects directly on volunteers' motivation. Moreover, training and development is an important factor to increase the performance of volunteers in NGOs during COVID-19 pandemic. Findings indicate that motivation of volunteers is differentiates according to volunteers' personalities (some of them need the achievement factor to feel of the satisfaction, some of them need the power factor, and some of them need affiliation to the organization). In this case the top management should analyze every volunteer's personality to apply the best way of satisfying needs of each one. The results approved research hypotheses and confirmed them. Findings support the literature review and confirm that these three needs play a major impact on the volunteer's productivity, and to be more practical, human resources managers can develop an online system which can be cover all the motivators that was mentioned by respondents above.

\section{CONCLUSION}

To conclude, motivation of volunteers is one of the most important tools to get a successful nonprofit organization, especially the scout organizations which have a big impact on societies. Although COVID-19 pandemic made the mission harder, this actually it is not impossible. For that reason, top management of NGOs should take in consideration McClelland's social needs theory and imply an effective online engagement system according to the characteristics of volunteers in the team. Volunteers who consider the achievement as a motivator must put them in a highly competitive environment and give them challenges to accomplish. However, to the volunteers who consider the power need as motivator, the NGOs must pay attention to their opinions and to be taken in consideration the delegation of responsibility. The refusing to delegate can have negative consequences as to miss out on valuable learning and growth opportunities. Moreover, volunteers who consider the affiliation as motivator, the organization must satisfy them by enhancing the feeling of that they are liked by others by treating them as a family member. This can imply an effective communication between top management and volunteers. Furthermore, training and development plan for volunteers must be enhanced to increase the performance teaching them new skills and techniques at work. Lastly, we can affirm that an increase in satisfying of McClelland's needs lead to an increase in the performance of volunteers in NGOs and scout organizations. Also, an increase in training and development of team lead to an increase of the productivity of volunteers during COVID19 pandemic. 


\section{Abdulkadir, E., Isac, N., \& Dobrin, C. \\ VOLUNTEER'S ENGAGEMENT: FACTORS AND METHODS TO INCREASE VOLUNTEER'S PERFORMANCE AND PRODUCTIVITY IN NGOS DURING COVID-19 PANDEMIC (SCOUT ORGANIZATIONS AS A MODEL)}

\subsection{Limitations and future research}

This research that has been undertaken has highlighted motivation aspects related to McClelland's motivation theory, so future researchers can include all kinds of motivators for volunteers in NGOs not just one theory.

Moreover, the technique that was used to collect data can be improved by asking more interpretable questions in the questionnaire instead of Likert scale.

Lastly, the questionnaire should include more volunteers from other different countries instead of just Arab countries to have comprehensive and accurate information.

\section{REFERENCES}

Baden, P. (2007). Scouting for boys. Dover Publications, New York

Brooks, A. (2002). Can Nonprofit Management Help Answer Public Management's "Big Questions"? Public Administration Review, 62(3), 259-266. Retrieved June 23, 2021, from http://www.jstor.org/stable/3110211

Folger, J. (2021). What is an NGO (Non- Governmental Organization)?

https://www.investopedia.com/ask/answers/13/what-is-non-government-organization.asp

Ireri, C. M. (2015). Influence of motivation on employee performance in non-governmental institutions: A case of Kenya Terni society in Embu. Publishing house: University of Nairobi http://erepository.uonbi.ac.ke/handle/11295/90485?show=full

Kassema, J. J., (2020). COVID-19 Outbreak: Is It a Health Crisis or Economic Crisis or Both? Case of African Counties, Development Economic: Macroeconomic Issues in Development Economies, 9(51): 4-15.

Lewis, D. (2009). Nongovernmental organizations, Definition and history. Chapter in book: International Encyclopedia of Civil Society.

Lim, K. F. (2014). "Non-formal education: scouting, schooling and teacher training", Chemistry in Australia, (October), page 33. https://www.researchgate.net/publication/270443339_Nonformal_education_Scouting_schooling_and_teacher_training

McClelland, D.C. (1961). The achieving society, Princeton, N.J., Van Nostrand

Millette, V., \& Gagné, M. (2008). Designing volunteers' tasks to maximize motivation, satisfaction and performance: The impact of job characteristics on volunteer engagement. Motiv Emot, 32(1): 11-22.

Mose, T. (2019). Determinants of employee performance in humanitarian international nongovernmental organizations based in Kenya, International Academic Journal of Human Resource and Business Administration, 3(7): 57-82

Neculaesei, A.N., Tatarusanu, M., Anastasiei, B., Dospinescu, N., Bedrule Grigoruta, M.V., Ionescu, A.M. (2019). "A Model of the Relationship between Organizational Culture, Social Responsibility and Performance", Transformations in Business \& Economics, 18(2A): 42-59.

Nencini, A., Romaioli, D. \& Meneghini, A.M. (2016). Volunteer Motivation and Organizational Climate: Factors that Promote Satisfaction and Sustained Volunteerism in NPOs. Voluntas 27(1): 618-639

Oak, C., Schoeffler, B. (2020). Motivating employees during the COVID pandemic, Insurance journal. (August 10). https://www.insurancejournal.com/magazines/mag-features/2020/08/10/578320.htm 
Abdulkadir, E., Isac, N., \& Dobrin, C.

VOLUNTEER'S ENGAGEMENT: FACTORS AND METHODS TO INCREASE VOLUNTEER'S PERFORMANCE AND PRODUCTIVITY IN NGOS DURING COVID-19 PANDEMIC (SCOUT ORGANIZATIONS AS A MODEL)

Osemeke, M. \& Adegboyega, S. (2017). Critical Review and comparison between Maslow, Herzberg and McClelland's theory of needs, Funai Journal of Accounting, Business and Finance, 1(1): 161173.

Pacesila, M. (2014). Analysis of key-motivators in the Romanian NGO environment, Quality Innovation Prosperity, 18(2): 20-36.

Rajamanikam, A. (2016). Scouting and education. Journal of Applied and Advanced Research, 1(1): 1-2

https://updatepublishing.com/journal/index.php/jaar/article/view/6678

QuestionPro, (2021). What is data analysis in research? https://www.questionpro.com/blog/dataanalysis-in-research/

Schmidt, J. (2016). Nature of NGO volunteers' and employees' motivation. Implication and recommendations for managerial staff, Problemy ZarzĖdzania, 14(3): 45-69.

Tonnoir, A., Ciotir, I., Scutariu, A-L., \& Dospinescu, O. (2021). A Model for the Optimal Investment Strategy in the Context of Pandemic Regional Lockdown. Mathematics, 9(9): 1058.

Veselovská, L., Závadský, J., \& Bartková, L. (2021). Consumer Behaviour Changes During Times of the COVID-19 Pandemic: An Empirical Study on Slovak Consumers. E\&M Economics and Management, 24(2): 136-152.

Wagner, A. (2015). Nonprofit Governance, Organizational Purposiveness and Design. Administrative Sciences, 5(4): 177-187.

World Organization of the Scout Movement. (2020). About Scouts for SDGs | World Scouting. (n.d.).

Retrieved June 23, 2021, from https://sdgs.scout.org/about-sdgs 